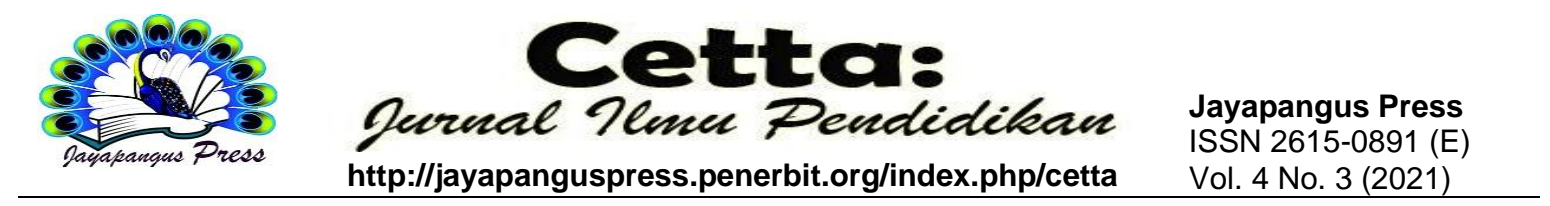

\title{
Urgensi Pendidikan Agama Hindu Terhadap Kebijakan Pemerintah Tentang Pendidikan Agama Dan Keagamaan
}

\author{
Ni Wayan Arini ${ }^{1}$, Gusti Nyoman Mastini ${ }^{2}$, Ni Ketut Kantriani ${ }^{3}$ \\ ${ }^{123}$ Universitas Hindu Negeri I Gusti Bagus Sugriwa Denpasar \\ ${ }^{1}$ wayanarini1967@gmail.com, ${ }^{2}$ nyomanmastini2@gmail.com, ${ }^{3}$ ketutkantriani@gmail.com
}

\begin{tabular}{l}
\hline Keywords: \\
\hline Urgency, Hindu \\
Religious \\
Education, \\
Government \\
Policies. \\
\hline
\end{tabular}

Abstract
Education and national development are closely related and both
are directed at the development of the entire Indonesian people.
As an effort to implement the National Education System Law,
the government hereby pays great attention to and prioritizes
religious education. In this case, the research aims to determine
the urgency of Hindu religious education and government
policies related to religious and religious education. This study
uses a qualitative method using descriptive analysis techniques.
Data were collected through literature study. The results of the
study state that Hindu religious education has a role in
encouraging the creativity of students to be able to do good and
right to achieve their life goals, as stated in the Vedas namely
Moksartham Jagadhitaya Ca Iti Dharma, which means people
can practice Hinduism, understand, appreciate and If you
practice it, then the purpose of life, namely physical and spiritual
well-being, will be achieved in this world and in the next life. It
is said how great the function of Hinduism is in shaping the
character of the nation's children, especially in ethics and
morality, developing spirituality in everyday life in order to
achieve their life goals. In this context, the government always
lists religious education as one of the compulsory subjects that
must be taken from elementary school to university. This is
reflected in the laws and regulations of the 1945 Constitution and
the National Education System Law, as well as other laws and
regulations.

Kata Kunci:

Urgensi,

Pendidikan

Agama Hindu,

Kebijakan

Pemerintah

\begin{abstract}
Abstrak
Pendidikan dan pembangunan nasional sangat berkaitan erat dan keduanya diarahkan untuk pembangunan seluruh rakyat Indonesia. Sebagai upaya melaksanakan UU Sisdiknas pemerintah dengan ini sangat memperhatikan dan mengedepankan pendidikan agama. Dalam hal ini, penelitian bertujuan untuk mengetahui urgensi pendidikan agama Hindu dan kebijakan pemerintah terkait pendidikan agama dan agama. Penelitian ini menggunakan metode yang kualitatif dengan menggunakan teknik analisis deskriptif. Data dikumpulkan
\end{abstract}


melalui studi kepustakaan. Hasil penelitian menyebutkan bahwa pendidikan agama Hindu memiliki peran dalam mendorong kreativitas peserta didik untuk dapat berbuat baik dan benar untuk mencapai tujuan hidupnya, seperti yang tertuang dalam Veda yaitu Moksartham Jagadhitaya Ca Iti Dharma, yang memiliki arti orang dapat mengamalkan agama Hindu, memahami, menghayati dan mengamalkan, maka tujuan hidup yaitu kesejahteraan lahir dan batin akan tercapai di dunia dan kehidupan selanjutnya. Dikatakan betapa pentingnya peran agama Hindu dalam membentuk karakteristik anak bangsa, khususnya dalam etika, serta moralitas, mengembangkan spiritualitas dalam kehidupan sehari-hari guna mencapai tujuan hidupnya. Dalam konteks ini, pemerintah selalu mencantumkan pendidikan agama sebagai salah satu mata pelajaran wajib yang harus ditempuh dari sekolah dasar hingga perguruan tinggi. Hal ini tercermin dalam peraturan perundang-undangan UUD 1945 dan UU Sisdiknas, serta peraturan perundang-undangan lainnya.

\section{Pendahuluan}

Pendidikan Nasional memiliki tujuan mencerdaskan kehidupan bangsa dan mengembangkan manusia Indonesia seutuhnya, yaitu manusia dan bangsa yang beriman dan bertakwa kepada Tuhan Yang Maha Esa, berakhlak mulia, pengetahuan dan keterampilan, kesehatan jasmani dan rohani, individualitas dan kemandirian, serta bertanggung jawab terhadap masyarakat. Mengingat pegangan hidup yang sangat penting bagi manusia adalah agama. Agama merupakan seperangkat nilai, pedoman, dan sistem yang mendorong manusia untuk menuju kualitas hidup yang lebih baik dan sempurna.

Uraian tentang hakikat dan urgensi membangun harmonisasi motivasi dan tantangan, serta penanaman karakter peserta didik dalam dunia pendidikan. Menurut ajaran Hindu, kesadaran peserta didik sebagai makhluk sosial berkembang dalam penyajiannya dalam bentuk penelitian urgensi Hindu. Melakukan pengajaran untuk menumbuhkan kesadaran siswa sebagai manusia sosial; menanyakan mengapa perlu untuk menumbuhkan kesadaran sosial siswa berdasarkan ajaran hindu; mempelajari sumber-sumber sejarah, sosiologis dan filosofis ajaran Hindu untuk meningkatkan kesadaran siswa sebagai manusia sosial, dan bagaimana membangun perilaku siswa berdasarkan ajaran Hindu. Kesadaran sebagai pribadi sosial menyajikan argumentasi, dan menggambarkan sifat dan urgensi membangkitkan kesadaran siswa sebagai pribadi sosial (Aryana, 2021). Diharapkan penyajian materi dan penelitian pengembangan yang 
dirumuskan dapat membantu mahasiswa dalam mengali pemahaman, penghayatan serta pengamalan pelaksanaan ajaran agama yang benar dan kualitasnya sebagai individu dan anggota dapat meningkatkan masyarakat, negara dan negara, dan dalam persaingan global. Kemampuan untuk bertahan hidup.

Melalui penelitian ini, para peserta didik juga diharapkan dapat meningkatkan kecerdasan, mutu dan kualitas diri, serta mampu menjadi umat Hindu dan bangsa Indonesia yang beriman terhadap Tuhan Yang Maha Esa dan taat (sraddha dan bhakti), berkualitas, mandiri dan selalu mampu membangun diri dan bertanggung jawab untuk pembangunan negara. Peserta didik tidak dapat terlepas dari pengaruh kehidupan sosial atau lingkungan, dimanapun, kapanpun, atau pada tingkat apapun, peserta didik tidak dapat lepas dari pengaruh kehidupan sosial atau lingkungan. Efek ini terkadang positif dan negatif. Oleh karena itu, di bawah pengaruh-pengaruh sosial atau lingkungan, yang terkadang tertarik pada hal-hal yang membingungkan atau cenderung menggulingkannya. Ironisnya, para pelajar saat ini lebih banyak melakukan hal-hal di luar tanggung jawabnya, seperti minum alkohol, menggunakan narkoba, menyimpan video berbau pornografi, dan lain sebagainya (Aryana, 2021). Begitu pula akhlak, tata krama, dan sopan santun sudah tak lagi dianggap suci. Degradasi moralitas seperti belenggu yang tidak lagi layak dipertahankan. Beberapa peserta didik saat ini ingin bertindak sesuai keinginannya sendiri, mengabaikan petunjuk atau aturan yang berlaku. Mengapa tsaat ini peserta didik terkadang enggan untuk melakukan perbuatan yang baik dan benar sesuai dengan ajaran agama? Inilah tantangan untuk melatih peserta didik agar sehat jasmani dan rohani, berakhlak mulia, maju, mandiri, bermartabat, dan beradab. Semua ini harus dihadapi.Terkait konteks ini, pemerintah secara konsisten telah melibatkan pendidikan agama sebagai salah satu mata pelajaran wajib yang harus ditempuh dari pendidikan sekolah dasar sampai perguruan tinggi. Hal ini tercermin dalam peraturan perundang-undangan UUD 1945 dan UU Sisdiknas, serta peraturan perundang-undangan lainnya.

\section{Metode}

Metode penelitian dalam penelitian ini yaitu menggunakan metode kualitatif dengan menggunakan teknik analisis deskriptif. Metode ini digunakan untuk menggali informasi yang lebih kompleks guna memperoleh informasi yang lebih banyak, yang berguna untuk pengembangan ilmu-ilmu sejenis. Data 
dikumpulkan melalui teknik pengumpulan data studi kepustakaan, yaitu membaca dan merekam data berupa ajaran-ajaran agama dan kebijakan pemerintah. Kemudian menganalisis data yang terkumpul menurut metode analisis data yang telah ditentukan, yaitu analisis kualitatif dan deskriptif. Metode ini dilakukan untuk mengetahui urgensi pendidikan agama Hindu terhadap kebijakan pemerintah tentang pendidikan agama dan keagamaan.

\section{Hasil dan Pembahasan}

Urgensi pendidikan Agama Hindu terhadap perkembangan pribadi peserta didik. Perlu dicatat bahwa, sebagaimana dinyatakan dalam Veda, tujuan agama Hindu yaitu "moksartham Jagadhitaya ca iti Dharma". Kalimat ini bermakna bahwa Dharma atau agama bertujuan untuk memajukan kehidupan yang sejahtera dan bahagia atau kebahagiaan lahir dan batin. Agama Hindu di tingkat pendidikan tak cukup hanya untuk dipelajari sebagai pengetahuan ataupun sebatas pemahaman saja, perlu dipraktikkan oleh setiap siswa agar mereka benar-benar dapat memikirkan dan mengihlami kehidupan yang damai dan damai berdasarkan ajaran agama. Peserta didik wajib selalu bertindak dan bertindak sesuai dengan ajaran agama, serta memiliki sifat, sikap dan watak yang luhur, serta kepribadian yang luhur, yang tercermin dalam kehidupannya di masyarakat, dan negara.

Pendidikan agama penting bagi setiap peserta didik karena memiliki pengaruh yang sangat positif terhadap perkembangan dan kemajuan karakter dan kepribadian. Atas dasar itu, pendidikan agama dari sekolah dasar hingga perguruan tinggi nampaknya sangat urgen, dan perlu untuk dipelajari sedini mungkin untuk membentuk dan mengembangkan pribadi yang berakhlak mulia. Sebagai peserta didik, berkewajiban untuk mengimplementasikan ilmu agama yang diperoleh selama studi ke dalam perilaku yang konkrit dan melakukan pengembangan lebih lanjut. Dengan ini, nantinya bisa menjadi panutan dalam pelaksanaan dan pengamalan ajaran agama berdasarkan sraddha dan bhakti kepada Tuhan Yang Maha Esa dalam kehidupan sehari-hari, dan diharapkan siswa akan menjadi pribadi yang benar-benar beragama, hidup damai dan bahagia. Dikeluarkannya UU RI No. 20 Tahun 2003 tentang Sistem Pendidikan Nasional dan Undang-Undang Nomor 12 Tahun 2012 tentang Pendidikan Tinggi, serta Peraturan Pemerintah Republik Indonesia Nomor 19 Tahun 2005 yang dirubah dengan Peraturan Pemerintah Republik Indonesia Nomor 32 Tahun 2013 tentang 
Standar Nasional Pendidikan yang isinya antara lain menegaskan bahwa pada tingkat Perguruan Tinggi wajib diajarkan mata kuliah pendidikan agama secara mandiri, dan memenuhi standar-standar tertentu. Oleh karena itu, mahasiswa harus dan wajib adanya untuk mendapatkan pendidikan agama. Pendidikan keagamaan ini pada hakikatnya merupakan pondasi yang kuat bagi siswa untuk melindungi diri dari berbagai ancaman yang melemahkan dan menghancurkan kehidupan mereka dari gangguan yang bersumber dari internal (diri sendiri) maupun eksternal (lingkungan). Agama merupakan sumber dorongan dan berperan sebagai solusi untuk memecahkan sebuah masalah atau problematika dalam kehidupan. Peserta didik wajib sadar bahwa agama harus dijadikan pedoman dan berjalan dengan sebaik-baiknya dan selalu berusaha mengamalkan ajaran agama HIndu.

Undang-undang No.20 Tahun 2003 tentang Sistem Pendidikan Nasional, menyatakan bahwa secara yuridis formal satuan pendidikan madrasah (kementerian Agama RI) dan sekolah (Kementerian Pendidikan Nasional RI) mempunyai kesamaan derajat di mata hukum. Sebagai konsekuensi dari Undang-undang tersebut terdapat beberapa peraturan, seperti Peraturan Pemerintah (PP), Peraturan Menteri Pendidikan Nasional (Permendiknas RI), serta Peraturan Menteri Agama (Permenag RI) sebagai peraturan yang menjelaskan tentang pendidikan secara teknis, operasional dari hirarki Undang-undang tersebut di atas maka lahirlah PP No. 55 Tahun 2007 tentang pendidikan Agama dan Keagamaan. Sebagaimana dalam Pasal 30 ayat (5), dan Pasal 37 ayat (3), UU Sisdiknas No.20 2003, mengingatkan perlunya menetapkan Peraturan Pemerintah tentang Pendidikan Agama dan Keagamaan.

Mengingat pentingnya penjelasan yang lebih rinci untuk pemajuan penerapan teknis sebagai pedoman di bidang ini, maka pemerintah merumuskan produk hukum berupa Peraturan Pemerintah (PP) Nomor 55 Tahun 2007 tanggal 5 Oktober 2007. Produk Hukum yang berupa Peraturan Pemerintah (PP) Nomor 55 Tahun 2007, ditetapkan oleh pemerintah yang dalam pengelolaannya sesuai dengan PP 55 2007, Pasal 9 (ayat 3), dilakukan oleh Menteri Agama. Peraturan Pemerintah Nomor 55 Tahun 2007 menyebutkan bahwa pendidikan keagamaan adalah pendidikan yang mempersiapkan peserta didik untuk dapat menjalankan peranan yang menuntut penguasaan pengetahuan tentang ajaran agama dan/atau menjadi ahli ilmu agama dan mengamalkan ajaran agamanya. 
Pendidikan berkaitan erat dengan pembangunan nasional dan diarahkan untuk pembangunan seluruh rakyat Indonesia. Pedoman normatif arah pembangunan ini mewujudkan tekad yang hendak dicapai bangsa Indonesia melalui pembangunan nasional terkait dengan rangka budaya dan sistem nilai bangsa Indonesia, yaitu menjaga nilai-nilai Ketuhanan Yang Maha Esa. Pendidikan agama bertujuan agar peserta didik memiliki sraddha dan bhakti (keyakinan dan ketakwaan) kepada Hyang Widhi Wasa (Tuhan Yang Maha Esa) berdasarkan ajaran agama yang diterima oleh peserta didik dan dengan memperhatikan syarat menghargai agama lain. Yang bertujuan untuk menjaga kerukunan antar umat beragama. Diamati dari peristiwa kehidupan, pendidikan agama termasuk agama Hindu akhir-akhir ini sedang mengalami perkembangan, lulusannya memiliki prospek kerja yang lebih banyak nantinya. Sebagai akademisi akan diminta untuk berdiskusi dan mengungkapkan keberadaan kecenderungan tersebut.

Mendeskripsikan hakikat dan urgensi ajaran agama Hindu dalam rangka menumbuhkembangkan individu yang humanistik anak didik. Pendidikan agama Hindu memiliki fungsi untuk memotivasi. Hal ini dapat menumbuhkan produktivitas peserta didik untuk melakukan perbuatan yang sesuai dengan ajaran agama guna mencapai tujuan hidup yang telah ditetapkan dalam Veda yaitu moksartham Jagadhitaya ca iti dharma, yang berarti melalui pemahaman, penghayatan dan pengamalan ajaran agama Hindu, maka hidup maknanya adalah menjadi kaya secara jasmani dan rohani dalam kehidupan ini dan nanti. Hakikat dan urgensi peran agama hindu dalam pendidikan tinggi dapat diartikan sejauh mana agama hindu berperan dalam membentuk kepribadian anak negara yang paling utama dari segi etika, moralitas dan spiritualitas, sikap keseharian mereka terhadap kehidupan, sehingga dapat mencapai tujuan hidupnya (Sutarwan, 2018).

Secara historis, perkembangan agama Hindu secara tradisional pertama kali dilakukan melalui pendidikan Pasraman. Sebelum dimulainya pembelajaran, terdapat sebuah upacara keagamaan yang disebut ritual Upanyana, upacara ini merupakan proses ritual di mana guru atau nabe meletakkan telapak tangannya di ubun-ubun siswa atau sisya, melambangkan bahwa semua kepribadian dituangkan ke dalam Sisya ( murid). /Mahasiswa). Perasaan cinta yang tercurah antara Acharya dan Sisya sudah menyatu, layaknya seorang anak dan orang tua. Batas usia Sisya bukanlah standar yang ketat. Pada prinsipnya, siapa pun dapat memulai pada titik yang dianggap tepat dalam memulai 
masuk dalam dunia pendidikan. Sisya (murid) wajib mentaati dan mengikuti peraturan yang berlaku.

Pendidikan agama Hindu dilaksanakan sebelum sekolah formal ada. Pendidikan agama Hindu dilakukan di pasraman-pasraman (ashram), pedepokanpedepokan dan tempat suci (pura) di seluruh Indonesia. Pada masa pra-kolonial, ajaran agama Hindu diambil alih oleh Guru Tiga. Yang merupakan tritunggal, yaitu Guru wisesa (kepala pemerintahan atau raja), Guru pengajian, yaitu, mereka berwenang untuk membimbing kehidupan spiritual, moralitas, dan urusan agama (bhagavanta, Bhagavan, pasiwan atau pasurya), dan Guru rupaka, guru yang diberi wewenang untuk memimpin pendidikan dalam keluarga. Dengan adanya sistem pendidikan sekolah (formal) yang dibawa oleh penjajah, pengajaran agama juga dilakukan di sekolah atau ashram. Selama ini sistem pendidikan Pasraman berkembang menjadi wadah untuk lebih memperkaya atau memperdalam pemahaman dan penguasaan ajaran agama Hindu. Pendidikan melalui praktik ini pertama kali dikembangkan di Bali dan Nusa Tenggara Barat, kemudian juga secara formal dan informal di daerah lain di Indonesia (Suda, 2017).

Urgensi peran pendidikan agama Hindu pada perguruan tinggi dapat diartikan bahwa agama Hindu memiliki peran dalam membentuk kepribadian anak bangsa, khususnya dalam aspek tata susila, moral dan spiritual dalam kehidupan sehari-harinya, sehingga dapat mencapai tujuan hidupnya. Melalui pendidikan agama Hindu pada tingkatan yang lebih tinggi, peserta didik hendaknya didorong untuk terus menggali pemahaman, penghayatan, dan pengamalan terkait ajaran agama, sehingga dapat mencapai tujuan hidupnya, yaitu hidup sejahtera, rukun, damai, dan bahagia (Setyaningsih, 2019). Pendidikan Agama Hindu banyak diampu oleh yayasan seperti Paruman Para Pandita, Majelis Hinduisme, Yayasan Dwijendra, Persatuan

Keluarga Bujangga Wisnawa, Bali Dharma Yajna, Satya Hindu Dharma. S ejak tahun 1968 pendidikan agama Hindu ditangani di sekolah seperti PGA Hind u, APGAH, STKIP Agama Hindu, STHD, UHN I Gusti Bagus Sugriwa, IAHN Gde Pudja Mataram, STAH N Mpu Kuturan yang hingga saat ini keberadaannya tersebar di beberapa daerah di Indonesia.

Pandangan tentang pertumbuhan dan perkembangan pendidikan agama Hindu dalam membangun landasan individu yang humanistik bagi peserta didik. Di era sekarang ini, dengan masyarakat yang semakin demokratis dan sistem pendidikan yang terus 
berubah, hal ini menjadi tantangan yang sangat besar bagi dunia pendidikan, khususnya bagi profesi guru. Metode-metode sebelumnya seringkali sangat otoriter, dan dengan asumsi bahwa pendidik mengetahui segalanya, tampaknya tidak lagi berlaku. Metode pendidikan hari ini harus lebih demokratis (Santika, 2018). Pendidikan merupakan sebuah proses, yakni proses pembentukan manusia Indonesia yang memiliki kepribadian yang utuh baik jasmani maupun rohani. Pola pengajaran telah bergeser dari penanaman karakter yang baik menjadi penanaman kecerdasan. Pada akhirnya, lembaga pendidikan menjadi pasar yang berkembang pesat dan produktif secara finansial. Pasalnya, hanya mereka yang mampu membayar biaya pendidikan tinggi di lembaga pendidikan yang dapat menjamah dan menikmatinya. Institusi pendidikan telah menciptakan kesenjangan yang sangat besar, karena hanya mereka yang mampu yang dapat menggunakan institusi tersebut, sehingga dapat terjadi ketidakadilan. Tanpa penggunaan bahan dan teknologi tinggi, calon sarjana dapat beralih ke lembaga pendidikan yang menghadirkan lembaga pendidikan yang lebih maju, modern, dan berkualitas lebih tinggi. Ada beberapa parameter dasar di sektor pendidikan. Semakin tinggi peralatan teknis yang disediakan, semakin tinggi pula biaya kuliah yang direkomendasikan. Semakin tinggi biaya pendidikan yang diusulkan, semakin banyak minat masyarakat yang dapat menembus model pendidikan ini. Tingginya minat masyarakat terhadap pendidikan berteknologi tinggi tersebut menunjukkan tingkat keberhasilan anggapan bahwa sektor pendidikan menguntungkan. Tampaknya dunia pendidikan itu mahal dan tidak terlepas dari dunia pesona. Untuk mencapai "harga" yang mahal tanpa mengorbankan "gengsi” pendidikan, pendidikan harus mahal dan sekaligus menyediakan fasilitas yang lengkap. Tanpa ini, hampir dapat dipastikan bahwa sektor pendidikan nantinya dapat ditinggalkan karena tuntutan prigprarisme.

Manajemen sekolah uggulan biasanya menyediakan fasilitas yang lebih luas dan lebih maju. Gengsi, kehormatan, dan kesinambungan dalam mempertahankan harga diri sangat diperlukan. Meskipun realisasi dunia spiritual diabaikan dalam pendidikan formal, yang meliputi nilai-nilai moralitas, etika, dan karakter, mengejar ketenaran di dunia spiritual merupakan hambatan menuju kehancuran spiritual. Bahkan setelah melepaskan posisi sekuler, keinginan untuk mendapatkan gelar masih ada di alam bawah sadar. Oleh karena itu, mereka yang mencari kebenaran harus mengabaikan seluruh tubuh, pikiran, dan jiwa mereka untuk fokus pada Tuhan dan tidak memiliki keinginan egois (Rama, $2002: 35$ ). 
Secara sosiologis, pendidikan agama Hindu yang membimbing pengembangan pribadi siswa bertujuan untuk semakin menumbuhkan kesadaran, bahwa kodrat kehidupan manusia tidak terlepas dari aspek sebagai makhluk ciptaan Tuhan, makhluk individu, dan makhluk sosial (Aryana, 2021). Untuk keempat aspek tersebut, manusia harus dapat hidup dan berkembang secara harmonis, serasi, seimbang, dan harmonis. Karena dengan ini, kita dapat menggapai tujuan hidup. Selanjutnya dari segi filosofis, landasan ajaran agama Hindu adalah untuk meningkatkan derajat hidup manusia itu sendiri, yang pada hakikatnya adalah penjelmaan di dunia untuk meningkatkan taraf hidupnya melalui perbuatan baik (Dharma). Tujuan hidup manusia dalam agama Hindu adalah mulia dan luhur, yaitu melepaskan diri dari kungkungan kehidupan maya. Melalui pendidikan agama, manusia nantinya dapat meningkatkan rasa percaya diri dan menghilangkan masalah-masalah tersebut. Atas dasar itu, pendidikan agama Hindu harus dilaksanakan, khususnya di tingkat pendidikan tinggi. Tidak cukup hanya mempelajari agama Hindu sebagai pengetahuan atau pemahaman, tetapi wajib diterapkan oleh setiap peserta didik agar dapat merenungkan kehidupan yang damai dan tentram.

Tingginya kesadaran masyarakat akan nilai-nilai agama menandakan bahwa bangsa Indonesia adalah bangsa yang beragama. Nilai religiusnya diwujudkan dalam sikap dan tata perilaku beragama dalam kehidupan sehari-hari dalam fungsinya, agama memberikan arahan bagi semua perilaku dan tindakan kita. Dalam hal pengembangan bakat khususnya bagi generasi muda, penyelenggaraan pendidikan di tingkat universitas dapat menyampaikan informasi moral dan nilai-nilai yang berharga, seperti kejujuran, kesopanan, disiplin, ketekunan, persatuan, kejujuran, kerukunan, persatuan dan kesatuan, nasionalisme, idealisme, patriotisme, kearifan lingkungan, integrasi nasional, harmoni tanggung jawab dan hak, penegakan hukum yang adil, gender, dan lainnya. Maka dari itu, nilai-nilai agama sangat perlu dikembangkan dalam bidang pendidikan.

\section{Kesimpulan}

Pendidikan Agama Hindu memiliki peran yang sangat penting sebagai pedoman yang dapat membantu mewujudkan kreativitas peserta didik untuk berakhlak mulia hingga dapat mencapai tujuan hidupnya. Seperti dijelaskan dalam Veda Moksartham Jagadhitaya Ca Iti Dharma, yang memiliki arti melalui pengamalan ajaran agama Hindu, pemahaman tentang agam Hindu, kemudian menghayati dan mengamalkannya, 
maka makna hidup yaitu kesehatan jasmani dan rohani, akan tercapai di dunia dan akhirat. Oleh karena itu, hakikat dan urgensi peran pendidikan agama Hindu dalam pendidikan dianggap begitu besar fungsinya dalam membentuk karakter anak bangsa, terutama dalam hal etika, moralitas, spiritualitas yang terapkan dalam kehidupan sehari-hari untuk mencapai tujuan hidupnya. Dalam hal ini, pemerintah secara konsisten telah melibatkan pendidikan agama sebagai salah satu mata pelajaran wajib yang harus ditempuh dari pendidikan sekolah dasar hingga perguruan tinggi. Hal tersebut tercermin dalam peraturan perundang-undangan UUD 1945 dan UU Sisdiknas, serta peraturan perundangundangan lainnya.

\section{Daftar Pustaka}

Armini, I. A. (2019). Urgensi Pendidikan Agama Hindu Bagi Anak. Pratama Widya: Jurnal Pendidikan Anak Usia Dini, 2(2), 58-70.

Aryana, I. M. (2021). Urgensi Pendidikan Karakter (Kajian Filsafat Pendidikan) . Kalangwan Jurnal Pendidikan Agama, Bahasa dan Sastra, 11(1), 1-10.

Karda. (2007). Sistem Pendidikan Agama Hindu. . Surabaya: Paramita.

Prasetiawati, E. (2017). Urgensi Pendidikan Multikultur untuk Menumbuhkan Nilai Toleransi Agama di Indonesia. Tapis: Jurnal Penelitian Ilmiah, 1(02), 272-303.

Pratiwi, N. K. (2018). Peran Pendidikan Agama Hindu Dalam Membentuk Kepribadian Siswa. Guna Widya: Jurnal Pendidikan Hindu, 2-5.

Rama, S. (2002). Hidup dengan Para Yogi Himaalaya. Surabaya: Paramita.

Santika, N. W. (2018). Pendidikan Agama Hindu Sebagai Dasar Dalam Pembentukan Karakter. Satya Widya: Jurnal Studi Agama, 1(2), 153-163.

Setyaningsih. (2019). Peran Pendidikan Agama Hindu Dalam Membentuk Kepribadian Siswa . Widya Aksara, 23 (2).

Suda, I. K. (2017). Pasraman Sebagai Energi Pendidikan Agama Dan Seni Hindu Dalam Dominasi Dan Hegemoni Pendidikan Modern. SOSHUM: Jurnal Sosial Dan Humaniora, 7(3), 364-373.

Sudarsana, I. K. ((2018, January 9). ). Pengantar Pendidikan Agama Hindu. Retrieved from https://doi.org/10.31227/osf.io/35qkb

Sutarwan, I. W. (2018). Urgensi Pendidikan Karakter Bagi Generasi Bangsa di Era Perkembangan Teknologi. Dharma Duta, 16(1). 